\title{
Budgetneutral trefrontskrig?
}

AF PETER VIGGO JAKOBSEN

SLAGMARK \#73

SIDER: 25I-255

Peter Taksøe-Jensen skal med sin udredning give et samlet bud på, hvordan Danmark mere effektivt kan håndtere de strategiske udfordringer, som Danmark står over for de kommende 10-15 år. Statsminister Lars Løkke Rasmussen har gjort klart, at han ønsker en mere målrettet og prioriteret dansk udenrigs- og sikkerhedspolitik. Denne målretning og prioritering skal ifølge statsministeren og hans udreder ske med udgangspunkt i Danmarks nationale interesser og noget, der minder om et geografisk nærhedsprincip.

Set med forsvarspolitiske øjne kunne udredningen ikke være timet bedre, fordi forsvaret fremover skal håndtere et øget pres på tre fronter samtidigt. Tidligere har forsvaret kunne nøjes med at håndtere én front af gangen. Under den kolde krig handlede det om at afskrække Sovjetunionen og Warszawapagten fra at angribe NATO. Siden da har opgaven været at bidrage til konflikthåndteringsoperationer stadig længere væk hjemmefra, men her har fokus typisk været på én stor mission af gangen. De næste 10-15 år tegner der sig imidlertid en situation, hvor der vil være behov for betydelige indsatser på tre fronter samtidigt.

Ruslands annektering af Krim i 2014, landets aktive destabilisering af det østlige Ukraine og den forøgede russiske aktivitet i Østersøen og Baltikum stiller krav om et øget dansk engagement som led i NATO’s bestræbelser på at afskrække Rusland fra at intimidere og destabilisere alliancens medlemslande. Danmark er under øget pres fra NATO for at øge sit forsvarsbudget og øge sine bidrag til den fælles håndtering af truslen fra øst. NATO ønsker et betydeligt større dansk hærbidrag end hidtil, hvilket vil være svært at finansiere inden for det eksisterende forsvarsbudget. 
Presset for en øget tilstedeværelse og træningsaktivitet på østfronten falder sammen med et øget behov for at stabilisere Nordafrika og Mellemøsten. Borgerkrigene i Libyen, Irak og Syrien har afstedkommet et flygtningepres på Europa, som den Europæiske Union (EU) har haft overordentlig svært ved at håndtere, og danske styrker har siden 2014 været indsat sammen med andre NATO-allierede i kampen mod Daesh i Irak/Syrien. Denne indsats blev i marts 2016 forstærket med specialstyrker og F-16 fly, således at det samlede danske bidrag når over 400 mand.

Endelig stiller afsmeltningen af isen i Arktis også forsvaret overfor øgede forpligtigelser med hensyn til overvågning, suverænitetshåndhævelse, redningstjeneste og miljøbeskyttelse i området omkring Grønland. En forstærket indsats i Arktis vil være nødvendig også selvom konfliktniveauet ikke stiger, og alle de fem arktiske kyststater, inklusive Rusland, fortsat indvilliger i at løse deres tvister på diplomatisk vis.

Nationale interesser er imidlertid ikke meget bevendt med hensyn til at prioritere indsatsen på disse tre fronter. Uanset hvordan man definerer Danmarks nationale interesser, kan man ikke komme udenom, at Danmark har stærke nationale interesser i at bidrage til håndteringen af dem alle tre. Det var da også statsministerens holdning i den kronik, hvor han forklarede formålet med udredningen for befolkningen. ${ }^{1}$ Peter Taksøe-Jensen er enig. Han sagde i forbindelse med sin udnævnelse som udreder, at flygtningestrømmen fra syd udgjorde en udfordring, som Danmark og EU var nødt til at prioritere. Han har siden tilføjet, at Danmark også er nødt til at tage den voksende trussel fra Rusland i Østersøregionen alvorligt, og at der er behov for en forøget prioritering af indsatsen i Arktis. ${ }^{2}$

Den interessebaserede tilgang tilsiger med andre ord, at forsvaret skal opprioritere indsatserne alle tre steder samtidigt inden for et forsvarsbudget, som må forventes at ligge nogenlunde konstant. Det er de færreste, der har fantasi til at forestille sig, at forsvarsbudgettet får et betydeligt løft i 2017, når det næste forsvarsforlig træder i kraft. Da Forsvarets Efterretningstjeneste i sine trusselsvurderinger ikke mener, at Danmark og NATO står over for en direkte militær trussel mod deres territorium, er det vanskeligt at se, hvordan forsvarsministeren skal kunne overbevise statsministeren og finansministeren om behovet for en betragtelig forøgelse af forsvarsbudgettet i en situation, hvor udgifterne til flygtninge og asylansøgere er eksploderet, og politiet, hospitalssektoren og ældreplejen alle skriger på flere ressourcer. Da udenrigs- og sikkerhedspolitikken ikke afgør folketingsvalg, er det svært at 
se forsvarsministeren vinde den prioriteringskamp. Det eneste, han kan hænge sin hat på, er en optrapning af russernes militære indsats i Ukraine og Østersøen og et massivt pres fra USA og NATO for større forsvarsudgifter. Sidstnævnte vil imidlertid kunne imødegås, såfremt Danmark hæver sit forsvarsbudget minimalt, så man i NATO og Washington kan fremvise en graf, der viser, at kurven er knækket, og at de danske forsvarsudgifter ikke falder mere.

Forsvaret skal løfte disse opgaver med stadig mindre enheder. Antallet af fly, skibe og soldater i Forsvaret har været støt faldende siden Murens fald, og det er en udvikling som vil fortsætte, selvom forsvarsbudgettet øges en smule, fordi både materiellet og personellet hele tiden bliver dyrere at anskaffe, anvende og holde opdateret. Eneste løsning er derfor rollespecialisering og tættere integration med de samarbejdspartnere som Danmark er afhængige af i en krisesituation. Dermed peger pilen på et fortsat tæt samarbejde med USA, som Danmark er afhængig af, uanset om lokummet begynder at brænde i Arktis, på østfronten eller på sydfronten. Hvis der skal vises eller anvendes militære muskler nogle af de steder, kan det kun ske med USA's aktive medvirken, hvis det skal have den ønskede effekt. Derfor nytter det ikke at lægge geografiske begrænsninger på, hvor vi vil operere ud fra et nærhedsprincip. Hvis Washington ringer og beder om militær assistance, vil der være en dårlig ide at sige nej med henvisning til geografi, hvis opgaven ellers er politisk spiselig og mulig for forsvaret. Danmark har interesser i det sydkinesiske hav, hvis USA siger det, fordi vi er afhængige af den amerikanske sikkerhedsgaranti i NATO, og fordi det er forudsætningen for at kunne blive ved med at bruge mindre end to procent af BNP på forsvaret uden at ende i skammekrogen i Washington og mindske sandsynligheden for, at USA vil hjælpe Danmark.

Pilen peger ligeledes på fortsat satsning på reaktionsenheder fra alle tre værn, som hurtigt kan indsættes der, hvor NATO stormagterne anser behovet for at være størst. Danmark har derfor valgt rigtigt ved at bidrage til NATO's nye hurtige reaktionsstyrke og den nye Joint Expeditionary Force (JEF), som Storbritannien står i spidsen for. Sidstnævnte er en hurtig udrykningsstyrke bestående af hær, flåde og flyenheder, som fra 2018 skal kunne indsættes med kort varsel i kampoperationer. Styrken skal kunne sammensættes til lejligheden og bruges der, hvor behovet opstår. Den kan indsættes i FN-operationer, NATO-operationer eller indgå i en koalition af villige. Udover Storbritannien og Danmark indgår de tre baltiske lande samt Holland og Norge også i styrken. Fordelen ved at indgå i disse to styrker er, at 
de begge vil blive indsat, hvor truslen imod NATO og Europa er størst på et givet tidspunkt. Hvis der opstår en krise på østfronten, vil Danmark via sin deltagelse i styrkerne bidrage der. Opstår der kriser i syd, vil den danske indsats blive dirigeret derhen. Deltagelsen i disse kampstyrker skaber således den mulighed for at lægge tyngde der, hvor Forsvaret gør den største forskel, som statsministeren efterlyser.

Derudover er der yderligere to fordele ved at prioritere Forsvarets deltagelse i disse to reaktionsstyrker. Den første er, at Forsvaret vil kunne fortsætte den specialisering i kampoperationer, som har fundet sted siden Murens fald. Den anden er, at deltagelsen i disse styrker gør det muligt at fortsætte det nære samarbejde med Danmarks tre strategiske allierede: Frankrig, Storbritannien og USA. JEF udgør nemlig den britiske komponent i en fælles britisk-fransk ekspeditionsstyrke, som ligeledes er under opbygning. Det betyder, at Danmark automatisk får mulighed for at bidrage til operationer, som briterne og franskmændene udfører i fællesskab. Derudover gør den det også muligt fortsat at bidrage til amerikansk-ledede indsatser, da JEF også vil være omdrejningspunktet for britiske bidrag til sådanne operationer.

I en situation med pres på tre fronter får vi mest goodwill og sikkerhed ved at kunne bruge militær magt der, hvor truslen opstår med kort varsel sammen med vores primære allierede. Danmarks sikkerhed afhænger af NATOs sammenhængskraft. Den styrker vi bedst ved at bidrage til reaktionsstyrker anført af stormagterne, som kan indsættes i både syd og øst efter behov.

De nævnte reaktionsstyrker er mindre anvendelige ved Arktis. Men her er den primære udfordring heller ikke militær. Den handler om tilstedeværelse, overvågning, miljøberedskab og søredning. De opgaver kan kun løses af de fem arktiske kyststater i fællesskab. Kommer det til en militær konfrontation med Rusland i Arktis, vil hele forsvarsbudgettet ikke slå til. Så må vi håbe, de tager telefonen i Washington.

\section{NOTER}

1 Lars Løkke Rasmussen. (2015, 15. september). Et lille land i en stor verden. Jyllands-Posten. Hentet fra http://jyllands-posten.dk/debat/kronik/ECE8020177/Et-lille-land-i-en-stor-verden/

2 Jakob Hvide Beim. (2016, 19. januar). Peter Taksøe-Jensen: Der er behov for yderligere fokusering og prioritering. Både geografisk og tematisk. Politiken. Hentet fra http://politiken.dk/ 
indland/ECE3022854/peter-taksoee-jensen-der-er-behov-for-yderligere-fokusering-og-prioritering-baade-geografisk-og-tematisk/; Ritzau. (2015, 15. september). Taksøe-Jensen ser migration som udfordring. Information. Hentet fra https://www.information.dk/telegram/2015/09/ taksoee-jensen-ser-migration-udfordring 